\section{Books on Agriculture}

ThE literature devoted to agriculture and allied sciences is now so extensive that the recent issue by the Ministry of Agriculture of Bulletin No. 78 entitled "A Selected and Classified List of Books on Agriculture" ( $6 d$. net) will be very widely welcomed. The books listed, together with many others, English and foreign, and many sets of periodicals, pamphlets and bulletins of agricultural experiment stations from all parts of the world, may be freely consulted in the Ministry's Library at 10 Whitehall Place, S.W.1, between the hours of 10 a.m. and 5 p.m. (Saturdays, 9.30 a.m. and 12.30 p.m.).

\section{Announcements}

WE regret to announce the death on January 16, at the age of seventy-nine years, caused by an accident while crossing a road in London, of Dr. F. A. Dixey, F.R.S., formerly subwarden, bursar and lecturer of Wadham College, Oxford, and president of the Entomological Society in 1909-10.

ON February 5, Brigadier M. N. MacLeod becomes director-general of the Ordnance Survey Department, Southampton, in succession to Brigadier H. St. J. L. Winterbotham, who has held the post since August, 1930.

Prof. E. V. Appleton, Wheatstone professor of physics in King's College, London, has been elected a corresponding member of the Prussian Academy of Sciences (Physico-Mathematical Class).

Prof. Orneneno Aber, lately professor of palæontology and palæobiology in the University of Vienna, has been appointed ordinary professor of geology and palæontology in the University of Göttingen, and director of the Geological and Palæontological Institute and Museum of the University.

The Progress Medal of the Royal Photographic Society of Great Britain has been awarded to $\mathrm{Mr}$. Harold Dennis Taylor in recognition of his inventions, researches and publications in optical science, which have resulted in important advances in the construction of photographic lenses and in the development of photography.

The Council of the Institution of Naval Architects has awarded the gold medal for the year 1934 to Vice-Admiral Y. Hiraga, professor of naval architecture and applied mechanics in the University of Tokyo, for his paper "Experimental Investigations on the Resistance of Long Planks and Ships", and the premium to Prof. B. P. Haigh, of the Royal Naval College, Greenwich, for his paper, "Further Tests and Result of Experiments on Electrically Welded Joints in Ship Construction". The medal and premium will be presented at the opening of the annual general meetings on Wednesday, April 10, at the Royal Society of Arts, John Street, London, W.C.2.
AT a reception given at the Collège de France on January 6, to the Assemblée de Médecine générale, addresses in memory of Claude Bernard, who made physiology the foundation of medicine, were delivered by Profs. Mayer and D'Arsonval. A visit was afterwards paid to Claude Bernard's laboratory in the Collège de France, where his table, instruments, early writings and manuscripts of his works are preserved.

AT the annual general meeting of the Royal Meteorological Society held on January 16 the following officers were elected : President, Lieut.-Col. Ernest Gold; Vice-Presidents, Prof. David Brunt, Dr. A. Crichton Mitchell, Dr. F. J. W. Whipple and Mr. W. M. Witchell ; Treasurer, Mr. R. A. Watson Watt; Secretaries, Dr. John Glasspoole, Mr. Eric Ludlow Hawke, Mr. M. McCallum Fairgrieve; Foreign Secretary, Mr. Charles J. P. Cave; New Members of Council, Mr. E. G. Bilham, Mrs. Charles J. P. Cave, Mr. C. S. Durst, Sir Gilbert Walker.

As the meeting of the Royal Microscopical Society on January 16, the following officers were elected: President, Prof. W. A. F. Balfour-Browne; VicePresidents, Mr. J. E. Barnard, Mr. Conrad Beck, Mr. D. M. Blair, Dr. R. S. Clay; Hon. Treasurer, Mr. C. F. Hill ; Hon. Secretaries, Prof. R. T. Hewlett, Mr. J. Smiles; New Members of Council, Mr. M. T. Denne, Dr. G. M. Findlay, Dr. E. E. Jelley, Mr. J. Milton Offord; Hon. Editor, Dr. G. M. Findlay; Hon. Librarian, Dr. Clarence Tierney; Hon. Curator of Instruments, Mr. W. E. Watson Baker; Joint Hon. Curators of Slides, Mr. N. I. Hendey, Mr. E. J. Sheppard.

The Jenner Memorial Medal for 1934 has been awarded to Sir George Buchanan, vice-president of the League of Nations Health Committee and Master of the Society of Apothecaries of London, 1934-35. The Jenner Memorial Medal was founded by the Epidemiological Society (now merged in the Royal Society of Medicine as the Section of Epidemiology and State Medicine) in "recognition of the greatest medical service ever done to man", in 1896 on the occasion of the Jenner centenary. It is awarded by the Council of the Royal Society of Medicine on the recommendation of the Section for distinguished work in epidemiological research or for pre-eminence in the prevention and control of epidemic disease.

Applications are invited for the following appointments, on or before the dates mentioned :-An agricultural organiser for the Wiltshire County Council-The Clerk, County Offices, Trowbridge (Jan. 31). An assistant for research on bonding materials in foundry sands in the British Cast Iron Research Association-The Director, 21 St. Paul's Square, Birmingham, 3 (Feb. 8). A senior lecturer in physics, two lecturers in mechanical engineering, an instructor in workshop practice and drawing, and an instructor in carpentry, building construction and geometry at the Lester School and Institute, Shanghai-The Lester Trust, Messrs. Viney, Price and Goodyear, Empire House, St. Martin's-le-Grand, London, E.C.1 (Feb. 25). 